\title{
Müşteri Deneyimi, Müşteri Tatmini ve Müşteri Sadakati Arasındaki İlişkinin İncelenmesi: Hazır Giyim Sektöründe Bir Araştırma
}

\author{
Sinan ÇAVUŞOĞLU*, Bülent DEMİRAĞ $\breve{G}^{* *}$
}

$\ddot{0} \mathbf{z}$

Araştırma giyim mağazalarını ziyaret eden tüketicilerin edinmiş oldukları deneyimin; müşteri tatmini ve sadakati üzerindeki etkisinin belirlenmesi amacıyla gerçekleştirilmiştir. Araştırmanın evrenini giyim üzerine tüketim yapan ve sıklıkla benzer giyim mağazalarını ziyaret eden tüketiciler oluşturmaktadır. Araştırmada hipotezlerin test edilmesi için Smart PLS 3 (Partial Least Squares) istatistik programı kullanılmıştır. Araştırmada ölçülmesi amaçlanan hipotezlerin testi için bootstrapping tekniği uygulanmıştır. Analiz sonuçlarına göre müșteri deneyiminin duyusal, duygusal, düşünsel ve ilişkisel boyutlarının müşteri tatmini ile istatistiksel olarak anlamlı bir ilişkiye sahip olduğu belirlenmiștir. Ayrıca müşteri deneyiminin duyusal, duygusal, düşünsel ve davranışsal boyutlarının müşteri sadakati ile benzer şekilde istatistiksel olarak anlamlı bir ilişkiye sahip olduğu tespit edilmiştir. Yapılan analizler neticesinde davranışsal boyutun müşteri tatminini; ilişkisel boyutun ise müşteri sadakatini etkilemediği sonucuna ulaşılmıştır.

Anahtar Kelimeler: Müşteri deneyimi, Deneyim ekonomisi, Deneyimsel modüller, Müşteri tatmini, Müşteri sadakati

\section{The Relationship between Customer Experience, Customer Satisfaction and Customer Loyalty: A Research on Clothing Sector}

\section{Abstract}

This study was conducted to determine the impact of the consumer experience, who visit clothing stores, on customer satisfaction and loyalty. The population of the study consists of consumers who consume clothing and frequently visit similar clothing stores. Smart PLS 3 (Partial Least Squares) statistical program was used to test the hypotheses. Bootstrapping technique was used to test the hypotheses intended to be measured in the study. According to the results of the analysis, the sensory, emotional, intellectual and relational dimensions of the customer experience have a statistically significant relationship with customer satisfaction. In addition, it was determined that the sensory, emotional, intellectual and behavioral dimensions of the customer experience have a statistically significant relationship similar to customer loyalty. As a result of the analysis,

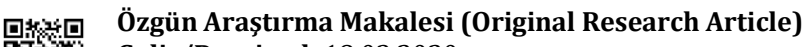

Geliş/Received: 18.03 .2020

Kabul/Accepted: 18.07 .2020

DOI: https://dx.doi.org/10.17336/igusbd.702365

* Öğr. Gör. Dr., Bingöl Üniversitesi, Sosyal Bilimler MYO, Yönetim ve Organizasyon, Bingöl, Türkiye, E-posta: sinankys42@gmail.com ORCID https://orcid.org/0000-0001-9365-8677

** Dr. Öğr. Üyesi, Gaziantep Üniversitesi, Oğuzeli MYO, Mülkiyet Koruma ve Güvenlik Programı, Gaziantep, Türkiye, E-posta: bulentdemirag@windowslive.com ORCID https://orcid.org/0000$\underline{0002-8718-1822}$ 
Sinan Çavuşoğlu, Bülent Demiră̆, "Müşteri Deneyimi, Müşteri Tatmini ve Müşteri Sadakati Arasındaki İlişkinin İncelenmesi: Hazır Giyim Sektöründe Bir Araştırma”, İstanbul Gelişim Üniversitesi Sosyal Bilimler Dergisi, 8 (2), Ekim 2021, ss. 316-336.

behavioral dimension did not affect customer satisfaction and relational dimension did not affect customer loyalty.

Keywords: Customer experience, Experience economy, Experiential modules, Customer satisfaction, Customer loyalty

\section{GíRiş}

İşletmeler son yıllarda rakiplerinden farkındalık oluşturmak için müşteri deneyimlerini daha fazla önemser hale geldiler. Modern pazarlama anlayışı, işletmeleri, ürettikleri ürünlerin satış sonrasında müşterilerinde yaşattı̆̆ deneyimleri anlamaya ve yönetmeye zorlamaktadır. Müşteri deneyimi kavramı, 1990'larda ve Pine ve Gilmore (1999)'un “Deneyim Ekonomisi” kitabında ele alınmış, ayrıca klasik iktisatçılar, deneyim ekonomisinin tüketici deneyimlerine yönelik kapsamlı değerlendirmeler içeren araştırmaların sonucu oluştuğunu belirtmişlerdir (Yazici, 2013: 25). Müșteri deneyimi, tüketici beklentileri ve hizmet değerlendirmelerine ilișkin yargısal ifadeler içermektedir. İşletmeler, belirledikleri amaçlara ulaşmak adına olumsuz müşteri deneyimi yaratan unsurları azaltıp, müşteri tatminini ve sadakatini güçlendirebildikleri takdirde rakiplerinden daha avantajlı konuma gelebilecekleri muhtemeldir.

İșletmeler tarafından müșteri tatmini ve sadakati oluşturulması, müşterilerin işletme ile olan güçlü ilişkisinin devam ettirilmesi rekabet avantajı elde etmek adına önemlidir. Tatmin olmuş ve bir markaya ya da kuruma sadakat duyan müşteriler, işletme ile olan ilişkisini devam ettirmeye yönelik güçlü bir niyete sahip oldukları için rakiplerin pazarlama çabalarına duyarsızlaşmakta hatta birer marka savunucusu haline dönüșmektedirler. Müșteri tatmini ve sadakatinin kişisel değerlendirmelere dayanmasından dolayı işletmelerin hedef pazarda yer alan müşterilerin ihtiyaç ve isteklerini anlamaları ve bunlara yönelik olumlu deneyim oluşturacak faaliyetlere yönelmeleri önemli gözükmektedir.

Gerçekleștirilen çalışmada müşteri deneyim boyutları Schmitt (1999)'in çalışmasında kullanıldığı gibi beș boyut (duyusal deneyim, duygusal deneyim, düșünsel deneyim, davranıșsal deneyim ve ilișkisel deneyim) olarak incelenmiștir. Her bir müșteri deneyim boyutunun, müşteri tatmini ve müşteri sadakati ile olan ilişkisi, hazır giyim sektöründe, müşteri algllarına ve değerlendirmelerine dayanarak incelenmektedir. Literatüre yönelik incelemelerde özellikle hazır giyim sektöründe değişkenler arası ilişkilere yönelik az sayıda çalışmanın yapıldığı görülmektedir. Hazır giyim sektörünün dinamikliği ve buna bağlı olarak tüketici beklentilerinin hızlı değişimi (De Klerk ve Tselepis, 2007) bu tür çalışmaların farklı kültür, sektör ve coğrafyalarda arttırılmasını yararlı kılacaktır. Bu çalıșma literatüre bu yönüyle katkı sunmayı amaçlamaktadır. Ayrıca müşteri deneyim boyutlarının her birinin müșteri tatmin ve sadakatini nasıl ölçtügünü belirlemesi çalışmanın alan yazında özgünlügünü ifade etmektedir.

\section{KAVRAMSAL ÇERÇEVE 2.1. Müşteri Deneyimi}

Müşteri deneyimi, iş ilişkisine bağlı olarak müşteri ile ürün ya da kuruluş arasındaki birtakım etkileşimler sonucunda oluşmaktadır (Gentile vd., 2007). Müşteri deneyimi, deneyimsel pazarlama kavramının temelini oluşturmaktadır (Çavuşoğlu ve Durmaz, 2020). Bir hizmeti deneyimlemek, müşterilerin hizmete ilişkin farklı duygularını (sevgi, korku, sürpriz, mutluluk, öfke vs.) ürüne yansıtması anlamına gelmektedir (Johnston ve Kong, 2011: 5). Verhoef vd. (2009), müşteri deneyiminin işletmeye yönelik düşünsel, duygusal, duyusal, sosyal ve fiziksel tepkilerden oluştuğunu belirtmektedir. Bu 
Sinan Çavuşoğlu, Bülent Demirağ, "Müșteri Deneyimi, Müşteri Tatmini ve Müşteri Sadakati Arasındaki İlişkinin İncelenmesi: Hazır Giyim Sektöründe Bir Araştırma”, İstanbul Gelişim Üniversitesi Sosyal Bilimler Dergisi, 8 (2), Ekim 2021, ss. 316-336.

yönüyle müşteri deneyimi, işletmenin kontrol alanı içinde kalan unsurlar (hizmet arayüzü, satış ortamı, ürün çeşitliliğ̈i, fiyat) ve kontrol alanı dışında kalan unsurların (diğer kişilerin etkisi, alışveriş amacı) bütüncül olarak değerlendirilmesini gerektirmektedir (Verhoef vd., 2009: 32). Gelişen iletişim teknolojileri müşterilerin deneyimlerini değișik kanallar aracılığıyla yansıtmaya olanak sağladığından işletmelerin pozitif müşteri deneyimleri oluşturmaları ve bu deneyimleri yönetmeleri önemli gözükmektedir (Lemon ve Verhoef, 2016). Shaw ve Ivens (2005: 149), pozitif müșteri deneyimi oluşturulabilmesinin yegâne şartının işletmenin kendisini ve müşteri kitlesini doğru yerde konumlandırmasına bağlı olduğunu belirtmektedir. Buna göre özyeterliklere dayalı ürün tekliflerin geçerliliğinin ve buna yönelik müșteri tepkilerinin kontrolü, deneyim modüllerini güçlendirecektir.

Deneyimsel pazarlama Schmitt (1999)'in deneyim modülü olarak oluşturduğu müşteri deneyim boyutlarından oluşmaktadır. Schmitt (1999: 60) işletmelerin tüketici ihtiyaçlarını karşılayabilmesi için geliştirmiş olduğu modelde deneyim boyutlarını duyusal, duygusal, düșünsel, davranıșsal ve ilişkisel olarak beș boyutta ele almaktadır. Yöneticilerin müşterileri için farklı türde deneyimler oluşturması stratejik deneyimsel modüller sayesinde gerçekleşmektedir. Modüller, farklı yapılara ve süreçlere sahiptir. Deneyimsel pazarlamada yönetilecek deneyimsel modüller arasında duyusal deneyimler (SENSE), duygusal deneyimler (FEEL), yaratıcı düşünsel deneyimler (THINK), davranışsal deneyimler (ACT) ve bunlarla ilişkili ilişkisel deneyimler (RELATE) bulunmaktadır.

Duyusal deneyim, beş duyu organımız olan görme, duyma, dokunma, tat ve koku alma yoluyla duyulara hitap eder (Nagasawa, 2008: 314). Yuan ve Wu (2008) duyusal deneyimi, müșterilerin mal veya hizmetlere yönelik algıladıkları bir mesaj olarak tanımlamışlardır. Duyusal deneyimin temel ilkelerinden birisi "bilişsel tutarlılık/duyusal çeşitliliktir". Yani ideal duyusal yaklaşım, net olarak algılanabilen fakat her zaman canlı ve yeniliğe yönelik temel bir kavram sağlar (Schmitt, 1999: 61). Mesela restoranlar tat ve lezzeti; oteller görselliği; tekstil ve giyim sektörleri ise dokunma duyularından yararlanmaktadırlar (Çavuşoğlu ve Durmaz, 2020).

Duygusal deneyim, müşterilerin içsel duygusunu ve mal/hizmetlerin tüketilmesi ile oluşan diğer duyguları yansıtır (Yuan ve Wu, 2008). Duygusal deneyim değişik şekillerde ortaya çıkar ve genellikle ılımlı ya da yoğun ruh halleri arasında değişir (Yang ve He, 2011: 6739). Mattila (2001: 74)'ya göre, deneyimdeki güçlü ve olumlu duygular, müşteri ilişkileri yönetimini de geliștirecektir. Duygusal deneyimin bașarı sağlaması adına, uyaranın, belirli duyguları tetikleyebilmesinin yanı sıra, tüketicinin bakış açısının ve empati istekliliğinin yakından kavranması önemlidir. Örneğin, standartlaşmış sıradan reklamlar, tüketim sürecindeki duyguları hedeflemediği için yetersiz kalacaktır (Çavuşoğlu ve Durmaz, 2020).

Düşünsel deneyim, tüketicinin bilişsel deneyimlerine dayanan bir deneyim türüdür (Lee vd., 2008: 220). Schmitt (1999: 61)'e göre düşünsel deneyim müşterinin yeni bir fikir geliştirmesinde veya bir şirket ya da ürünleri hakkında yaratıcı düşünmesi için onları harekete geçiren deneyim türüdür. Yeni bir fikir veya düşünmenin teşvik edilmesi yoluyla, tüketiciler şirkete ve markasına yönelik içsel değerlendirmelerini oluştururlar. Schmitt'e göre başarılı bir düşünsel deneyim, görsel, söylemsel veya zihinsel açıdan müşterilerin şaşırtılması (sürpriz), ilgilerinin çekilerek teşvik edilmesi yoluyla geliștirilmektedir.

Davranışsal deneyim, fiziksel deneyimlere odaklanarak, yaşam tarzlarını ve alternatif yaşam biçimlerini etkilemeyi amaçlamaktadır. Davranış değişikliği; analitik, rasyonel yaklaşımlar ve birçok davranışsal değişim alternatiflerinden sadece bir tanesidir. Davranışsal deneyim aracılığı ile tüketiciler, mal veya hizmetlere ilişkin bir his, etki ve ilişkisellik duygusu geliştirirler. Tüketici yaşam tarzları ve davranışsal değişiklikler genellikle doğada daha fazla motive edici, ilham verici duygusal bağlayıcılığı 
Sinan Çavuşoğlu, Bülent Demirağ, "Müşteri Deneyimi, Müşteri Tatmini ve Müşteri Sadakati Arasındaki İlişkinin İncelenmesi: Hazır Giyim Sektöründe Bir Araştırma”, İstanbul Gelişim Üniversitesi Sosyal Bilimler Dergisi, 8 (2), Ekim 2021, ss. 316-336.

olan rol modeller (örneğin, film yıldızları veya ünlü sporcular) kullanılarak oluşturulur (Schmitt, 1999: 62). Örneğin Nike firması, reklamlarda, sık sık ünlü sporcuları hareket halindeyken görselleștirerek, bir davranıșsal deneyim oluşturmaktadır. Reklamlar, ünlü rol modelleriyle özdeșleşme ihtiyacına hitap ederek, müşteri deneyimi oluşturur ve müşteriyi eyleme yönlendirir (Egan, 1998).

İlişkisel deneyim, mal ve hizmetlerin satın alma ve kullanım sürecinde, tüketicilerin sosyal topluluklar ve sosyal kurumlar ile bağlantı kurmasını sağlar (Chang vd., 2011: 309). Diğer ifadeyle ilişkisel deneyim, tüketicinin kendini geliştirmesi, başkaları tarafından olumlu algılanması ve bireyi bir sosyal topluluğa dâhil etmeye yarar. İlişkisel deneyim, esasında diğer müşteri deneyim boyutlarının tüm değerlendirmelerini kapsayan bir deneyim türüdür. Bireyi kişisel duyguların ötesine tașıyarak, mevcut durumun dişına çlkarır (Gültekin ve Kement, 2018: 122).

\subsection{Müşteri Tatmini}

Literatürde müşteri tatminine yönelik birçok değerlendirmeye rastlanılmaktadır. Howard ve Sheth (1969)'a göre müșteri, işletmeler tarafından, beklentilerini karşılayacak düzeyde ödüllendirildiği durumlarda tatmin yaşayacaklardır. Westbrook ve Reilly (1983) müşteri tatminini, ürüne yönelik deneyimlere dayanan, duygusal bir karşılık olarak ifade etmektedirler. Bir başka değerlendirmede müşteri tatmini, tüketicilerin ürüne ilişkin satın alma öncesi beklentileri (ödül vs.) ile satın alma sonrası içsel değerlendirmelerini (masrafların karşılanması) kapsayan karşılaştırmalara dayanmaktadır (Gilbert vd., 1982). Schmitt (1999), müşteri tatmininin, olumlu ve güçlü bir müşteri değerine dayandığını belirtmektedir. Diğer ifadeyle müşteri, ürün satın alma sürecinde ya da sonrasında (bilgiye ulaşma, alternatif ürün faydası vs.) katlandı̆̆ı maliyetleri, kullanım sonrasında elde ettiği faydalarla karşılaştırma sonrasında olumlu değer algılarsa tatmin, diğer durumda tatminsizlik oluşacaktır. Oliver (1999), müşterilerin önceki beklentileri ile ürünün sağladığı gerçek performansa yönelik algılanan tutarsızlıkların müșteri tatmine yönelik sonuçlar içerdiğini belirtmektedir. Mal veya hizmetin yaşam seyrinde müșterinin ihtiyaç duyduğu, istediği ve beklentilerinin karşılandığı veya tekrarlandığı durum, tatmin, tekrar satın alma, sadakat ve elverişli ağızdan ağıza iletişim gibi işletme lehine sonuçlar içermektedir (Brown, 1992).

İşletmeler, ihtiyaçların dinamikliğine bağlı olarak pazarı segmentlere ayırırlar ve müşterilerinin ihtiyaçlarına çözüm üretecek faaliyetlere yönelirlerse güçlü bir müşteri tatmini yaratabilirler (Ilieska, 2013: 327). Tatmin olmuş müşterilerin işletmeye sağlayacağı en önemli avantaj sadakate ilișkindir. Buna göre müşteriler ürüne ilişkin olumlu deneyim yaşadıklarında rakiplerin pazarlama çabalarına duyarsızlaşır ayrıca ilişki kalitesine bağlı olarak etkileşim kalitesini arttırılabilirler. Bu sayede işletmeler, yeni müşteri elde etmeye yönelik maliyetleri asgari seviyeye indirebilirler (Ihalainen, 2011: 16).

Müşteri tatminini etkileyen faktörler farklı endüstrilerde farklı gerekçelere dayanmaktadır (Anderson vd., 1994; Huh, 2002). İşletmeler, üretim faaliyetlerinde hangi faktörlerin daha fazla tatmin yarattığını öngörmek niyetindedirler. Ancak, tüketicilerin kişisel özellikleri, beklenti farklılıkları, sektör özellikleri vs. içsel ve dışsal faktörler, bir ürüne yönelik tatmin oluşturan tüm faktörlerin anlaşılmasını zorlaştırmaktadır. Bu nedenle tatmini ölçmeye yönelik çabalar, tatmin yaratan faktörlerin ancak genel bir değerlendirmesine yardımcı olmaktadır (Demirağ ve Durmaz, 2020: 79). Örneğin, hazır giyim gibi üretim ve hizmet faaliyetlerinin bir arada yürütüldüğü işletmelerde ürün kalitesi ve hizmete ilişkin faaliyetlerin tatmin ölçümünün süreçlere yararlı olacaktır. Mesela ürünün fiziksel kalitesinden memnun olan bir tüketicinin çalışan davranışlarından hoşnutsuzluk yaşaması durumunda yaşadığı tatminsizliği ürün kalitesine yansıtması 
Sinan Çavuşoğlu, Bülent Demirağ, "Müșteri Deneyimi, Müşteri Tatmini ve Müşteri Sadakati Arasındaki İlişkinin İncelenmesi: Hazır Giyim Sektöründe Bir Araştırma”, İstanbul Gelişim Üniversitesi Sosyal Bilimler Dergisi, 8 (2), Ekim 2021, ss. 316-336.

olasıdır. Zira müşteri tatmin seviyesi, hizmete yönelik kalite algısını güçlendirmekte/azaltmakta ve davranıșsal niyetleri etkilemektedir (Dovalienè vd., 2007: 64). Bir başka örnek, havayolu taşımacılığına ilişkindir. İnsanlar, ulaşımı kendileri için tercih ettiklerinde bazı unsurları (pahalı fiyata rağmen konfor, emniyet, yiyecek-içecek hizmetleri vs.) tatmin için ön koşul gibi algıladıkları halde, taşımanın konusu tüketiciye ait evcil hayvan ya da bir eşya olduğunda tatmine yönelik faktörlere ilişkin beklentiler farklılaşabilmektedir. Müșteri tatmini, kuşkusuz her yönüyle pazarlama stratejilerinin odak noktasını oluşturmaktadır.

\subsection{Müșteri Sadakati}

Müşteri sadakati kavramına ilk kez değinen araştırmacı olarak kabul edilen Brown (1952), tekrarlı satın alma davranışının müşteri sadakatini yansıttığını belirtmektedir. Bu değerlendirme, müşteri sadakatini salt davranış olarak ölçmektedir. Day (1969), müşterilerin tercih ettikleri markaya yönelik olumlu tutuma sahip olduklarında tekrarlı satın alma eylemine (davranışa) yöneleceklerini belirtmektedir. Bu tanımlama, müșteri sadakatinin hem "tutum" hem de "davranış" olarak birlikte değerlendirilmesi gerektiği konusunda salt "davranışa" odaklanan önceki çalışmaları (Cunningham, 1961; Harary ve Lipstein, 1962) genişletmiş, daha sonraki çok boyutlu çalışmaların da önünü açmıştır. Tutum boyutunun (gelecekteki davranışları öngörmede yetersiz bir veri sunduğu) gerekçesiyle müşteri sadakati değerlendirmelerinde dikkate alınmamasını öngören geleneksel müşteri sadakati yaklaşımlarına rağmen (Tucker, 1964; Backman ve Crompton, 1991) tutum ve davranışın müșteri sadakatini izah etmede birlikte ele alınmasına yönelik çok sayıda değerlendirme ve ampirik çalışma bulunmaktadır. Newman ve Werbel (1973: 405), ürüne/markaya ilişkin olumlu deneyim yaşayan müşterilerin güvene dayalı olumlu tutuma ve tekrarlı satın alma davranışına yöneleceğini belirtmektedirler. Jacoby ve Kyner (1973: 2-3) müşteri sadakatini, "zaman içinde bir dizi marka dışında bir veya daha fazla alternatif markaya ve psikolojik süreçlerin bir fonksiyonu olan karar verme birimi tarafından ifade edilen davranışsal tepki" olarak ifade etmektedirler. Ajzen ve Fishbein (1980), müșteri sadakatine ilișkin geliștirdikleri Düşünülmüş Eylem Teorisi'nde müşteri rasyonel seçim sürecinin davranışa yönelik tutum gelişimini güçlendirdiğini belirtmişlerdir. Dick ve Basu (1994), müşteri sadakatinin tutum ve davranışa yönelik kompozit yapısını desteklemiş, müşteri sadakat tipolojisinde gerçek sadakat/sahte sadakat arasındaki ayrımın tutum ve davranışın bir sonucu olduğunu belirtmişlerdir. Buna göre müșterinin bir ürün ya da markaya yönelik güçlü tutum ve davranış sergilemesi gerçek müşteri sadakatini; öte yandan düşük tutum ancak yüksek satın alma davranışı sergilemesi sahte müșteri sadakatini yansıtmaktadır.

Oliver (1997; 1999), müşteri sadakatini "durumsal etkilere veya pazarlama çabalarına rağmen, tüketicilerin geçmiște deneyimledikleri mal ya da hizmeti sürekli bir biçimde tekrardan satın alma veya tekrar kullanma konusundaki taahhütleri" olarak tanımlamaktadır. Oliver'in müşteri sadakatine ilişkin en önemli katkısı tutumsal boyuta ilişkin önerdiği hiyerarşik düzendir. Buna göre müşteri sadakatinin tutum boyutları; bilişsel (cognitive), duygusal (affective) ve çabasal (conative) ve nihayetinde davranışsal/eylemsel (behavioural) olarak kategorize edilmiştir. Bilişsel sadakat, müşteri sadakatinin ilk aşamasıdır ve ürün bilgisine dayanır. Bu aşamada müşteri değeri ön plandadır ve daha güçlü değer sunan alternatifler, müșteri sadakatinin yönünü etkileyebilir (Evanschitzky ve Wunderlich, 2006: 331-332). Duygusal sadakat aşaması, bilişsel boyutun müşteri zihninde bıraktığı olumlu kanının duygusal bir boyuta dönüşmesidir (Han vd., 2008: 24). Çabasal aşama ise çoğunlukla eylemle sonuçlanan davranışsal niyetleri ifade etmektedir (Radder ve Han, 2013: 1262). Müşteri bu aşamada ürüne/markaya yönelik bilișe sahip olup, olumlu duygularına dayanarak ürün için çaba 
Sinan Çavuşoğlu, Bülent Demirağ, "Müșteri Deneyimi, Müşteri Tatmini ve Müşteri Sadakati Arasındaki İlişkinin İncelenmesi: Hazır Giyim Sektöründe Bir Araştırma”, İstanbul Gelişim Üniversitesi Sosyal Bilimler Dergisi, 8 (2), Ekim 2021, ss. 316-336.

göstermeye ve beklemeye razı olmuștur. Bu çaba (ürünün bir yerde bulun(a)maması, pazara çıkma süresinin beklenmesi vs.) olarak kendini gösterebilir. Bu yüzden müşteri sadakatinin davranışsal aşamasının oluşması, tutumsal bileșenlerin gücü ile doğrudan ilişkilidir.

\section{KURAMSAL ÇERÇEVE}

\subsection{Müşteri Deneyimi/Müșteri Tatmini İlișkisi}

Alan yazında gerçekleştirilen çalışmalarda genel olarak müşteri deneyiminin müşteri tatminini etkilediği sonucu hakimdir (Trini ve Salim, 2018; De Klerk ve Tselepis, 2007; Mbama ve Ezepue, 2018; Lee vd., 2019; Yu vd., 2017; Borishade vd., 2018; Barari vd., 2019). Trini ve Salim (2018), Jakarta'da 200 otel müșterisine yönelik çalışmalarında müşteri deneyim boyutlarının müşteri tatmini üzerinde olumlu yönde anlamlı etkisi olduğu sonucuna ulaşmışlardır. De Klerk ve Tselepis (2007), hazır giyim sektöründe genç kadın müşterilere yönelik gerçekleștirdikleri çalışmalarında kadın müșterilerin sadece kıyafetlerinin ișlevsel fayda sağlayan fiziksel kalite unsurlarıyla (uygunluk gibi) ilgilenmediklerini, bunun yanı sıra duygusal deneyime yönelik sonuçlarını da önemsediklerini tespit etmişlerdir. Çalışma sonucunda, deneyim yaratan duygusal bileșenlerin irdelenmesinin önemli olduğu vurgulanmıștır. Mbama ve Ezepue (2018), Birleşik Krallık'ta dijital banka kullanıcıları üzerine gerçekleștirmiş oldukları çalışmalarında, bankaların üstün finansal performans algısına dayalı müşteri deneyimlerinin güçlü bir müşteri tatmini olușturduğu sonucuna ulaşmışlardır. Lee vd. (2019), New York şehrindeki otellerde konaklayan müşterilerin hizmet deneyimlerinin müşteri tatmini üzerindeki etkilerini düşünsel çabalar ve duygusal değerlendirmeler açısından incelemişler, müşterilerin düşünsel çabalar içeren deneyimlerinin müşteri tatmini üzerinde olumsuz etkisi olduğu sonucuna ulaşmışlardır. Yu vd. (2017), Amerika Birleșik Devletleri'nde yeșil otellerde konaklayan müşterilerin deneyimlerinin müșteri tatminine olan etkisini araştırmış oldukları çalışmalarında değerlendirmelerinin müşteri tatmini üzerinde anlamlı bir etkisi olduğu sonucuna ulaşmışlardır. Borishade vd. (2018), Nijerya Lagos eyaletinde özel hastanelerde sağlık hizmeti alan 365 katılımcı ile gerçekleştirdikleri çalışmalarında, sağlık hizmetlerine ilişkin müşteri deneyimlerinin müşteri tatmini üzerinde olumlu yönde anlamlı bir etkiye sahip olduğunu tespit etmişlerdir.

Barari vd. (2019), hizmet başarısızlıklarına ilişkin müșteri deneyiminin müşteri tatminine yönelik etkilerini araştırdıkları 201 katılımcı ile gerçekleștirilen ilk çalışmalarında hizmet başarısızlıkları algısının olumsuz duygusal ve düşünsel deneyime neden olduğunu böylelikle her iki deneyim boyutunun müșteri tatminsizliği ve negatif ağızdan ağıza iletişim yarattığı sonucuna ulaşmışlardır. Çalışmadaki 200 kişilik farklı örneklemden elde edilen sonuçlara bakıldığında, başarılı bir alışveriş sonrasında müșteri deneyim boyutlarından duygusal deneyimlerinin öncelikle etkilendiği, hizmet başarısızlıkları durumlarında ise müșterilerin öncelikle deneyimledikleri duygusal deneyimden düşünsel deneyime geçiş yaşadıkları tespit edilmiştir. Sonuçlar, müşterilerin deneyim boyutlarının hizmete ilişkin değerlendirmelere bağlı olarak değiștiğini ve müşteri tatminin yönünü etkilediğini ortaya çıkarmıştır.

Alanyazında gerçekleştirilen çalışmalar ışığında aşağıdaki hipotezler geliştirilmiştir:

$H_{1}$ : Müşteri deneyimi ile müşteri tatmini arasında istatistiksel olarak anlamlı bir ilişki vardır.

H1a: Duyusal deneyim ile müșteri tatmini arasında istatistiksel olarak anlamlı bir ilişki vardır. 
Sinan Çavuşoğlu, Bülent Demirağ, "Müșteri Deneyimi, Müşteri Tatmini ve Müşteri Sadakati Arasındaki İlişkinin İncelenmesi: Hazır Giyim Sektöründe Bir Araştırma”, İstanbul Gelişim Üniversitesi Sosyal Bilimler Dergisi, 8 (2), Ekim 2021, ss. 316-336. ilișki vardır.

$H_{1 b:}$ Duygusal deneyim ile müşteri tatmini arasında istatistiksel olarak anlamlı bir ilişki vardır.

$H_{1 c}$ : Düşünsel deneyim ile müşteri tatmini arasında istatistiksel olarak anlamlı bir ilişki vardır.

$H_{1 d:}$ Davranısssal deneyim ile müşteri tatmini arasında istatistiksel olarak anlamlı bir ilişki vardır.

H1e: İlişkisel deneyim ile müşteri tatmini arasında istatistiksel olarak anlamlı bir

\subsection{Müşteri Deneyimi/Müşteri Sadakati İlişsisis}

Literatürde, hazır giyim sektöründe deneyim ve sadakat değişkenleri arasındaki ilişkiyi inceleyen çalışmalara rastlanılmaktadır. Fernando vd. (2018), Sri Lanka'da hazır giyimde moda ürünleri tercih eden tüketiciler üzerinden gerçekleştirdikleri çalışmada müşteri deneyiminin duyusal, duygusal, düşünsel ve davranışsal boyutlarının marka sadakati üzerinde pozitif etkisi olduğu sonucuna ulaşmışlardır. Huong vd. (2016), Vietnam Da-Nang üniversitesinde uluslararası iki giyim markasını kullanan 18-35 yaşları arasındaki 285 katılımcı ile gerçekleştirdikleri çalışmada müşteri deneyiminin tüm boyutlarının marka sadakati ile pozitif bir ilișkiye sahip olduğu sonuçlarına ulașmıșlardır. Shim vd. (2015), Amerika Birleşik Devletleri'nde bir hazır giyim markasından online alışveriş yapan 20-34 yaş aralığındaki 400 katılımcı ile gerçekleştirdikleri çalışmada deneyim boyutlarının marka sadakati üzerindeki etkisini incelemişler, duyusal ve duygusal deneyim boyutlarının marka sadakati üzerinde pozitif etkisi olduğu sonucuna ulaşmışlardır.

Müșteri deneyimi/müșteri sadakati arasındaki ilişkinin farklı endüstrilerde de incelendiği görülmektedir. Imbug vd. (2018), Malezya'da 248 telekomünikasyon müşterisine yönelik çalışmalarında müşteri deneyiminin müşteri sadakati üzerinde pozitif bir etkiye sahip olduğunu tespit etmişlerdir. Benzer şekilde Wijaithammarit ve Taechamaneestit (2012), Tayland'da gerçekleştirdikleri çalışmalarında müșteri deneyiminin müşteri sadakati üzerinde etkili olduğu sonucuna ulaşmışlardır. Ali vd. (2014), Malezya'nın iki önemli turizm bölgesi kabul edilen Langkawi ve Penang'da 450 resort otel müşterisi ile gerçekleștirdikleri çalışmalarında, müşteri deneyim boyutlarını deneyimsel değerle ilişkilendirerek (eğitimsel deneyim, eğlence deneyimi, estetik deneyimi, kaçış deneyimi) boyutların tamamının müşteri sadakati ve müşteri hafızası (memory) üzerinde anlamlı bir etkisi olduğu sonucuna ulaşmışlardır. Çalışma, deneyimsel değer ve boyutlarına yönelik kavramsal değerlendirmelerde birlikte ele alınan eğlence ve kaçış deneyimini, ayrı boyutlar olarak değerlendirerek deneyim ekonomisinin anlaşılmasında derinlemesine bir çerçeve sunmuştur. Benzer şekilde Kement ve Çavuşoğlu (2017) da yeşil otelleri ziyaret eden otel müşterilerinin hafızaya dayalı deneyimlerinin (eğitim, eğlence, estetik ve kaçış) müşteri sadakati üzerine etkisini belirlemek amacıyla gerçekleștirdikleri çalıșmalarında eğlence ve estetik deneyimin sadakati anlamlı bir şekilde etkilediği sonucuna ulaşmışlardır.

Alanyazında gerçekleștirilen çalışmalar ışığında aşağıdaki hipotezler geliştirilmiştir:

$\mathrm{H}_{2}$ : Müșteri deneyimi ile müssteri sadakati arasında istatistiksel olarak anlamlı bir ilişsi vardır.

$H_{2 a}$ : Duyusal deneyim ile müşteri sadakati arasında istatistiksel olarak anlamlı bir ilişki vardır.

$H_{2 b:}$ Duygusal deneyim ile müssteri sadakati arasında istatistiksel olarak anlamlı bir ilişki vardır. 
Sinan Çavuşoğlu, Bülent Demiră̆, "Müşteri Deneyimi, Müşteri Tatmini ve Müşteri Sadakati Arasındaki İlişkinin İncelenmesi: Hazır Giyim Sektöründe Bir Araştırma”, İstanbul Gelişim Üniversitesi Sosyal Bilimler Dergisi, 8 (2), Ekim 2021, ss. 316-336. ilişki vardır.

$H_{2 c}$ : Düşünsel deneyim ile müșteri sadakati arasında istatistiksel olarak anlamlı bir bir ilişki vardır.

$H_{2 d}$ : Davranışsal deneyim ile müşteri sadakati arasında istatistiksel olarak anlamlı ilişki vardır.

$\mathrm{H}_{2 e}$ : Illişkisel deneyim ile müşteri sadakati arasında istatistiksel olarak anlamlı bir

\subsection{Müşteri Tatmini/Müşteri Sadakati İliş̧kisi}

Müșteri tatmini, bir işletmenin karlılığının ve sürdürülebilir rekabet avantajı kazanmasının önemli bir adımını oluşturmaktadır. Fornell (1992), müşteri sadakatinin, müşteri tatmininin bir sonucu olduğunu vurgulamaktadır. Müşteri tatmini, müşterilerin ürüne yönelik beklentileri ile performans arasındaki değerlendirme sonucunda oluşmaktadır (Gilbert vd., 1982). Ürün performansı, müşteri beklentilerini aştığı durumlarda müșterilerin ürüne yönelik olumlu tutum geliștirmesi ve nihayetinde tekrarlı satın alma davranışı gerçekleştirmesi muhtemeldir. Chen ve Wang (2009), müşteri tatmininin işletmeye sağlayacağı avantajları; aynı ürüne yönelik tekrarlı satın alımlar, fiyat duyarlılığın azalması, sadık müșteri kitleleri olușturma ve ürüne yönelik pozitif ağızdan ağıza iletișim olarak değerlendirmektedir. Özellikle fiyat duyarlı̆̆ının azaltılması ve sadık müşteri kitlesinin işletmeye kazandırılması, yeni müşteri elde etmek amacıyla düzenlenen kampanyaları ve tutundurmaya yönelik müşteri tavizlerini azaltmaya yardımcı olacaktır. Müşteri tatmininin ișletmelere yönelik bu olumlu kazanımlarına dayanarak literatürde müşteri tatmininin "müșteri sadakati" gibi sonuç değişkenlerine yönelik çalıșmaların sayısında artış yaşanmıștır (Al-Msallam, 2015; Leninkumar, 2017; Nguyen vd., 2018).

Sheng ve Liu (2010), Çin'de hazır giyim, mobilya, kitap, yazılım ve dijital ürünlere yönelik online satın alma davranışı sergileyen 164 tüketici üzerinden gerçekleştirdikleri çalışmada, müşteri tatmininin müşteri sadakati üzerinde pozitif etkisi olduğu sonucuna ulaşılmışlardır. Kandampully ve Suhartanto (2000), Yeni Zelanda'daki zincir otellerde konaklayan müşterilere yönelik çalışmalarında, müşteri tatmini, otel imajı ile müșteri sadakati arasında güçlü bir ilişki olduğunu tespit etmişlerdir. Drake vd. (1998), müșteri tatmini ve müşteri sadakatinin her ikisinin işletmeler açısından önemli bir argüman olduklarını belirtmiş, çalışmalarında müşteri tatmini ve müşteri sadakati oluşturan öncülleri hem nitel hem de nicel yöntemler açısından incelemişlerdir. Fraering ve Minor (2013), finansal kuruluşlardan hizmet alan 493 tüketiciye yönelik çalışmalarında, müșteri tatmini ve müşteri sadakatinin (bilişsel, duygusal, çabasal ve davranışsal boyutlarının) finansal kuruluşlarla ticarete devam etme konusundaki cesaret duygusu ile pozitif ilişkili olduğu sonucuna ulaşmışlardır. Diğer ifadeyle müșteri tatmini ve müşteri sadakati, belirsizlik ve risk unsurunun yüksek olduğu finans sektöründe dahi müșteri cesaretini arttırarak işletmelere mevcut müşterileri elde tutma konusunda avantaj sağlamaktadır. Martín-Consuegra vd. (2007), müşteri tatmini ve müşteri sadakatinin algılanan fiyat adaletinden etkilendiğini, öte yandan her iki değişkenin müşterilerin fiyat tolerans sınırlarının belirlenmesinde önemli birer öncül oldukları sonucuna ulaşmışlardır. Nobar ve Rostamzadeh (2018), otel sektöründe müşteri tatmini ve müşteri sadakati arasındaki ilişkiyi incelemişler, 384 otel müşterisinden topladıkları veriler sonucunda, müşteri tatmininin en önemli belirleyicisinin müșteri beklentileri olduğunu ayrıca müşteri tatmininin müşteri sadakati üzerinde pozitif etkiye sahip olduğu sonuçlarına ulaşmışlardır. Arokiasamy (2013), Malezya'da banka müşterisi olan 165 müşteri üzerinden gerçekleştirmiş olduğu çalışmasında, müşteri tatmini ve müşteri sadakati arasında güçlü bir ilişkinin olduğunu tespit etmiștir. 
Sinan Çavuşoğlu, Bülent Demirağ, "Müșteri Deneyimi, Müşteri Tatmini ve Müşteri Sadakati Arasındaki İlişkinin İncelenmesi: Hazır Giyim Sektöründe Bir Araştırma”, İstanbul Gelişim Üniversitesi Sosyal Bilimler Dergisi, 8 (2), Ekim 2021, ss. 316-336.

Alanyazında gerçekleştirilen çalışmalar ıșığında aşağıdaki hipotez geliştirilmiştir: H11: Müşteri tatmini, müşteri sadakati üzerinde pozitif bir etkiye sahiptir.

\section{YÖNTEM}

Araştırma giyim mağazalarını ziyaret eden tüketicilerin edinmiş oldukları deneyimin; müşteri tatmini ve sadakati üzerindeki etkisinin belirlenmesi amacıyla gerçekleştirilmiştir. Araştırmanın evrenini giyim üzerine tüketim yapan ve sıklıkla benzer giyim mağazalarını ziyaret eden bireyler oluşturmaktadır. Araştırma kapsamında evreninin çok geniş olması nedeniyle tesadüfi olmayan örneklemelerden 'kolayda örneklem' yöntemi uygulanmıştır. Evreni temsil edebileceği göz önünde bulundurularak örneklem sayısı 425 anket formunda yer alan verilerden yola çıkarak değerlendirilmiştir.

Anket formu demografik sorular ve belirlenen modelin tespiti amaciyla ankete eklenen ölçek sorularından oluşmaktadır. İlk bölümde katılımcıların demografik özelliklerinin belirlenmesi amacıyla yaşanılan yer, cinsiyet, yaș, eğitim, medeni durum ve gelir seviyesi soruları sorulmuştur. İkinci bölümde müșteri deneyimini ölçmek için 22 soru (Nadiri ve Gunay, 2013), müşteri tatminini ölçmek için 5 soru (Wang vd., 2004) ve müşteri sadakatini ölçmek için 4 soru (Ali vd., 2014) yer almaktadır. İkinci bölümde yer alan soruları ölçmek için kullanılan ifadeler beşli likert ölçeğine uyarlanarak "kesinlikle katılmıyorum, kesinlikle katılıyorum" (1-5) aralığında katılımcılara yöneltilmiştir.

Araştırmaya katılan bireylerin demografik özellikleri incelendiğinde; ankete katılanların 201'i erkek $(\% 47,3)$ ve 224'ü kadın $(\% 52,7)$ tüketicilerden oluşmaktadır. Katılanların \%42,6'sının (n: 181) yaş aralığının 25-34 arasında olduğu, medeni durum incelendiğinde katılımcların \%51,3'ünün (n:218) evli olduğu tespit edilmiştir. Araştırmaya katılan bireylerin eğitim durumları incelendiğinde \%39,5'nin (n:168) lisans düzeyinde eğitim aldığı ve gelir seviyesinin \%82,6 ile orta olduğu tespit edilmiştir (n: 351).

Araştırmada hipotezlerin test edilmesi için Smart PLS 3 (Partial Least Squares) istatistik programı kullanılmıștır. Hair vd. (2011)'ne göre PLS-SEM, araștırmanın özelliklerine ve toplanan verilerin niteliğine uygun olarak birçok yapı, değişken ve yapısal yolun tahmin edilebilmesine olanak sağlayan bir modeldir. Bu seçim ilk olarak çalışmanın araştırıcı niteliği nedeniyle yapılmıştır. İkincisi, ölçümler Likert ölçeği ile geliştirildiği için, verilerin normal olmayan bir veri dağılımı vardır. PLS herhangi bir normallik varsayımı gerektirmez ve normal olmayan dağılımları nispeten daha iyi hesaplamaktadır. PLS-SEM, çok boyutluluk düzeyleri içeren bir araştırma modelinin anahtar hedef yapılarındaki tahmin ve varyansın genişletilmesi üzerine yapılan çalışma için de uygun bir tekniktir (Ali vd., 2018). Araştırmada ölçülmesi amaçlanan hipotezlerin testi için bootstrapping tekniği uygulanmıştır. Ölçülmesi hedeflenen araştırma modeli şu şekildedir; 


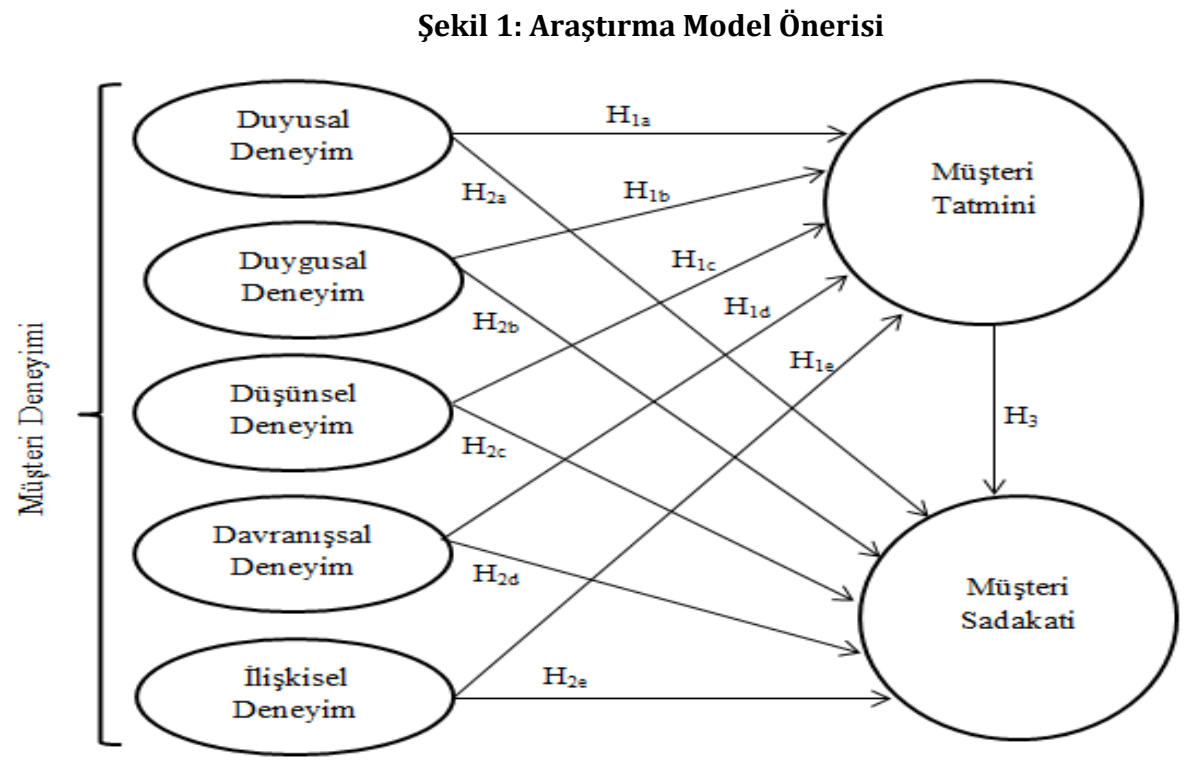

\subsection{Araştırma Modeli Geçerlilik ve Güvenilirlik Sonuçları}

Müşteri deneyimi boyutları (duyusal, duygusal, düşünsel, davranışsal ve ilişkisel), müşteri tatmini ve müşteri sadakatinin ayrım geçerliliği sonuçları Tablo 1 ve Tablo 2'de detaylı olarak gösterilmektedir.

Tablo 1: Ayrım Geçerliliği ve Tanımlayıcı İstatistikler

\begin{tabular}{|l|l|l|l|l|l|l|l|l|l|l|}
\hline \multicolumn{2}{|c|}{ Değișkenler } & $\mathbf{X}$ & $\mathbf{S D}$ & $\mathbf{1}$ & $\mathbf{2}$ & $\mathbf{3}$ & $\mathbf{4}$ & $\mathbf{5}$ & $\mathbf{6}$ & $\mathbf{7}$ \\
\hline $\mathbf{1}$ & $\begin{array}{l}\text { Duyusal } \\
\text { Deneyim }\end{array}$ & 3,98 &, 723 & $\mathbf{0 , 8 0 5}$ & & & & & & \\
\hline $\mathbf{2}$ & $\begin{array}{l}\text { Duygusal } \\
\text { Deneyim }\end{array}$ & 3,78 &, 786 &, 560 & $\mathbf{0 , 8 9 6}$ & & & & & \\
\hline $\mathbf{3}$ & $\begin{array}{l}\text { Düşünsel } \\
\text { Deneyim }\end{array}$ & 3,67 &, 800 &, 561 &, 626 & $\mathbf{0 , 8 3 8}$ & & & & \\
\hline $\mathbf{4}$ & $\begin{array}{l}\text { Davranışsal } \\
\text { Deneyim }\end{array}$ & 3,57 &, 874 &, 443 &, 454 &, 606 & $\mathbf{0 , 8 8 6}$ & & & \\
\hline $\mathbf{5}$ & $\begin{array}{l}\text { Illişkisel } \\
\text { Deneyim }\end{array}$ & 3,43 &, 784 &, 464 &, 529 &, 554 &, 570 & $\mathbf{0 , 8 2 3}$ & & \\
\hline $\mathbf{6}$ & $\begin{array}{l}\text { Müșteri } \\
\text { Tatmini }\end{array}$ & 3,84 &, 866 &, 566 &, 645 &, 651 &, 495 &, 658 & $\mathbf{0 , 7 9 0}$ & \\
\hline $\mathbf{7}$ & $\begin{array}{l}\text { Müșteri } \\
\text { Sadakati }\end{array}$ & 3,74 &, 860 &, 560 &, 654 &, 625 &, 561 &, 478 &, 615 & $\mathbf{0 , 8 7 9}$ \\
\hline
\end{tabular}

Araştırma modelinin geçerliliğini belirlemek için yapı, ayrım ve uyum geçerlilikleri incelenmiştir. Ayrım geçerliliğini belirlemek için AVE değerlerinin karekökü ve Heterotrait-Monotrait (HTMT) hesaplanmıștır (Fornell ve Larcker, 1981; Hair vd., 2010). Uyum geçerliliğini belirlemek için ortalama açlklanan varyans (AVE) ve bütünleşik güvenilirlik (CR) değerleri incelenmiştir. Yapı geçerliliğini belirlemek için ise doğrulayıcı 
Sinan Çavușoğlu, Bülent Demirağ, "Müșteri Deneyimi, Müșteri Tatmini ve Müșteri Sadakati Arasındaki İlișkinin İncelenmesi: Hazır Giyim Sektöründe Bir Araştırma”, İstanbul Gelişim Üniversitesi Sosyal Bilimler Dergisi, 8 (2), Ekim 2021, ss. 316-336.

faktör analizi hesaplanmıştır. Güvenirlik ve geçerlik sonuçları Tablo 2'de detaylı olarak gösterilmektedir.

Tablo 2: Güvenirlik ve Geçerlik Sonuçları

\begin{tabular}{|c|c|c|c|c|c|}
\hline \multicolumn{2}{|c|}{ Ölçekler ve İfadeler } & $\alpha$ & CR & AVE & $\lambda$ \\
\hline \multirow{8}{*}{$\begin{array}{l}\text { Duyusal } \\
\text { Deneyim }\end{array}$} & $\begin{array}{l}\text { Mağazada görsel olarak çekici ürünler } \\
\text { bulunmaktadır. }\end{array}$ & \multirow{8}{*}{,92 } & \multirow{8}{*}{,93 } & \multirow{8}{*}{,64 } & 820 \\
\hline & $\begin{array}{l}\text { Mağazada hizmetlerle ilişkili materyaller (broşürler, } \\
\text { tanıtımlar, bildirimler vb.) görsel açıdan dikkat } \\
\text { çekicidir. }\end{array}$ & & & & ,798 \\
\hline & Mağazada iç ve dıș dekorasyonlar ilgi çekicidir. & & & & 803 \\
\hline & $\begin{array}{l}\text { Mağazada çalınan müzikler rahatlatıcı ve huzurlu bir } \\
\text { atmosfer sunmaktadır. }\end{array}$ & & & & 832 \\
\hline & Mağazada güzel ve etkileyici koku vardır. & & & & ,792 \\
\hline & $\begin{array}{l}\text { Mağazada satılan ürünler benim beklentilerimi } \\
\text { karşılamaktadır. }\end{array}$ & & & & 834 \\
\hline & Mağazada sunulan ürünler yenidir. & & & & ,773 \\
\hline & Mağazadaki mobilyalar temiz ve konforludur. & & & & ,782 \\
\hline \multirow{3}{*}{$\begin{array}{l}\text { Duygusal } \\
\text { Deneyim }\end{array}$} & Mağazada kendimi rahat ve mutlu hissediyorum. & \multirow{3}{*}{,87 } & \multirow{3}{*}{92} & \multirow{3}{*}{,80 } & ,892 \\
\hline & Mağaza rahatlatıcı ve samimi bir atmosfere sahiptir. & & & & ,902 \\
\hline & $\begin{array}{l}\text { Mağazada çalıșanlar beklentilerimi yeterince } \\
\text { karşılamaktadır. }\end{array}$ & & & & 895 \\
\hline \multirow{4}{*}{$\begin{array}{l}\text { Düşünsel } \\
\text { Deneyim }\end{array}$} & $\begin{array}{l}\text { Mağazada dikkatimi çeken farklı etkinlikler } \\
\text { düzenlenmektedir. }\end{array}$ & \multirow{4}{*}{,85 } & \multirow{4}{*}{90} & \multirow{4}{*}{, 70} & ,858 \\
\hline & $\begin{array}{l}\text { Mağaza içerisinde günlük gelişmeleri takip etmemi } \\
\text { sağlayan basılı ve görsel iletişim kanalı ve internet } \\
\text { bağlantısı vardır. }\end{array}$ & & & & ,856 \\
\hline & $\begin{array}{l}\text { Mağaza ile ilgili en son haberleri web sitelerinden } \\
\text { takip ediyorum. }\end{array}$ & & & & 869 \\
\hline & $\begin{array}{l}\text { Mağaza ile ilgili medyada çıkan haberleri takip } \\
\text { ediyorum. }\end{array}$ & & & & ,765 \\
\hline \multirow{3}{*}{$\begin{array}{l}\text { Davranısssal } \\
\text { Deneyim }\end{array}$} & $\begin{array}{l}\text { Mağaza beni yaşam tarzı hakkında düşünmeye teşvik } \\
\text { ediyor. }\end{array}$ & \multirow{3}{*}{,86 } & \multirow{3}{*}{91} & \multirow{3}{*}{,78 } & 894 \\
\hline & $\begin{array}{l}\text { Mağaza bana yapabileceğim etkinlikleri hatırlatmaya } \\
\text { çalışıyor. }\end{array}$ & & & & 877 \\
\hline & Mağaza davranıșlarımı düșünmemi sağlıyor. & & & & ,887 \\
\hline \multirow{4}{*}{$\begin{array}{l}\text { İlişkisel } \\
\text { Deneyim }\end{array}$} & $\begin{array}{l}\text { Mağaza sosyal çevrem ile iliş̧i kurmamda bana } \\
\text { yardımcı oluyor. }\end{array}$ & \multirow{4}{*}{,84 } & \multirow{4}{*}{89} & \multirow{4}{*}{,67 } & ,785 \\
\hline & $\begin{array}{l}\text { Aynı sosyal ortamı paylaştığım arkadaşlarım bu } \\
\text { mağazayı tercih ettiği için bende tercih ediyorum. }\end{array}$ & & & & ,799 \\
\hline & $\begin{array}{l}\text { Mağazanın müssterisi olmak ait olduğum sosyal sınıfın } \\
\text { aktivitelerinden birisidir. }\end{array}$ & & & & ,883 \\
\hline & $\begin{array}{l}\text { Bu mağazada olduğumda doğru yerde olduğumu } \\
\text { hissediyorum. }\end{array}$ & & & & 821 \\
\hline \multirow{5}{*}{$\begin{array}{l}\text { Müșteri } \\
\text { Tatmini }\end{array}$} & $\begin{array}{l}\text { Bu mağazanın hizmetleri daima beklentilerimi } \\
\text { karşılar. }\end{array}$ & \multirow{5}{*}{,84 } & \multirow{5}{*}{ 89 } & \multirow{5}{*}{ 62 } & 840 \\
\hline & $\begin{array}{l}\text { Diğer mağazalarda yaşadığım deneyimlere dayanarak } \\
\text { bu mağazanın hizmetlerinden memnun kaldım. }\end{array}$ & & & & ,556, \\
\hline & $\begin{array}{l}\text { Mağazanın sunduğu hizmetler daima beklenen } \\
\text { düzeydedir. }\end{array}$ & & & & 865, \\
\hline & $\begin{array}{l}\text { Mağazanın sunduğu hizmeti benim için uygun } \\
\text { zamanlarda alabiliyorum. }\end{array}$ & & & & 847, \\
\hline & $\begin{array}{l}\text { Mağazanın sunduğu hizmet beklentilerimden } \\
\text { fazlasını karşılamıștır. }\end{array}$ & & & & 802, \\
\hline $\begin{array}{l}\text { Müşteri } \\
\text { Sadakati }\end{array}$ & $\begin{array}{l}\text { Siklıkla ziyaret ettiğim mağazayı başkalarına tavsiye } \\
\text { edeceğim. }\end{array}$ & ,90 & ,93 & ,77 & 875 \\
\hline
\end{tabular}




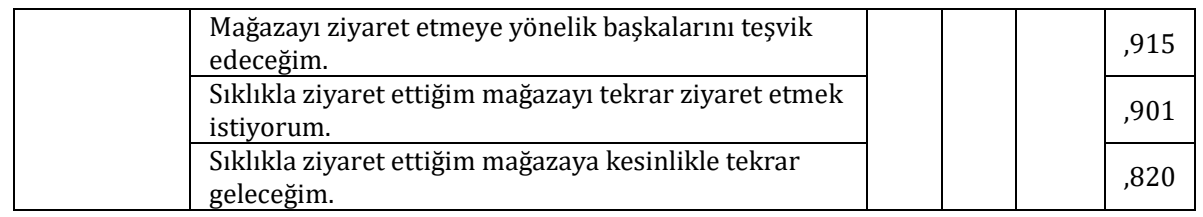

* 5'li likert ölçek (1=Kesinlikle Katılmıyorum, 3=Kararsızım, 5=Kesinlikle Katıllyorum).

* $\lambda=$ Faktör yükleri, CR=Bütünleşik güvenilirlik (Composite reliability), AVE=Ortalama açıklanan varyans (Average variance extracted), $\alpha=$ Cronbach Alpha

Ölçeklere ait her bir ifadenin faktör yüklerinin 0,50'in üzerinde (Kaiser, 1974) dolayısıyla yapı geçerliliğine sahip olduğu (Fornell ve Larcker, 1981) tespit edilmiştir. CR değerlerinin 0,70'in üzerinde (Hair vd., 2012) ve AVE değerlerinin 0,50'nin üzerinde (Fornell ve Larcker, 1981) olduğu, dolayısıyla araştırma modelinin uyum geçerliliğine sahip olduğu görülmektedir (Bknz. Tablo 2).

Uyum iyiliği değerleri benzer şekilde Smart PLS 3 (Partial Least Squares) istatistik programı ile incelenmiş elde edilen kriterler Tablo 3'te gösterilmiștir.

Tablo 3: Model Uyum İndeksleri

\begin{tabular}{|c|c|c|c|}
\hline & $\chi^{\mathbf{2}}$ & NFI & SRMR \\
\hline Kriter & & $\geq, \mathbf{8 0}$ & $\leq, \mathbf{0 8}$ \\
\hline & $1,739.062$ & 0,81 & 0,056 \\
\hline
\end{tabular}

Gerçekleştirilen analiz sonucunda değişkenlere ait $\chi^{2}$ değerinin 1,739.062 olarak tespit edilmiștir. Normlaştırılmış uyum indeksi (normed fit index, NFI) değerlerinin 0,80'in üzerinde olduğu belirlenmiştir (Yaşlıoğlu, 2017: 77). Evrene ait kovaryans matrisi ile örnekleme ait kovaryans matrisi arasındaki artık kovaryansları temsil eden SRMR (standardized Root Mean Square Residual) değerinin ise 0,08'in altında olması modelin kabul edilebilirliğine işaret etmektedir (Hu ve Bentler, 1999). Elde edilen sonuçlara göre araştırma modelinin iyi bir uyum iyiliğine sahip olduğu tespit edilmiştir.

Ayrım geçerliliğini belirlemek için AVE değerlerinin karekökü ve HeterotraitMonotrait (HTMT) hesaplanmıştır (Fornell ve Larcker, 1981; Hair vd., 2010). FornellLarcker kriterine göre, örtük değişkenin AVE değerinin karekökü, yapıdaki diğer tüm örtük değişkenlerle olan korelasyonundan daha büyük olmalıdır (Hair vd., 2019). AVE değerinin karekökü Tablo 1'de koyu renkli verilerdir. Bu değerler, bulundukları satır ve sütunlardaki diğer değerlerden büyük olduğundan, ayrım geçerliliğinin sağlandığı ifade edilebilir.

Araştırma modelinde yer alan değișkenlerin her birinin farklı bir kavramı ölçtüğünü tespit etmek için ayrım geçerliliği (discriminant validity) HeterotraitMonotrait (HTMT) ile ayrıca hesaplanmıștır. Hesaplama sonuçlarına göre HTMT değerinin 0,9'un altında olması durumunda ayrım geçerliliğinin sağlandığı öne sürülebilir (Henseler vd., 2009). Tablo 4'te modele ilişkin HTMT oranları verilmiştir. Bu sonuçlara göre, değişkenler arasındaki HTMT oranı 0,90'ın altında olup ayrım geçerliliği onaylanmıştır. Değişkenlerin birbirlerinden farklı oldukları sonucuna varılmıştır. 
Tablo 4: Heterotrait-Monotrait (HTMT) Değerleri

\begin{tabular}{|l|l|l|l|l|l|l|}
\hline Değişkenler & $\mathbf{1}$ & $\mathbf{2}$ & $\mathbf{3}$ & $\mathbf{4}$ & $\mathbf{5}$ & $\mathbf{6}$ \\
\hline 1 Duyusal Deneyim & & & & & & \\
\hline 2 Duygusal Deneyim & 0,620 & & & & & \\
\hline 3 Düşünsel Deneyim & 0,627 & 0,718 & & & & \\
\hline 4 Davranışsal Deneyim & 0,494 & 0,522 & 0,709 & & & \\
\hline 5 İlişkisel Deneyim & 0,517 & 0,607 & 0,650 & 0,669 & & \\
\hline 6 Müșteri Tatmini & 0,631 & 0,736 & 0,749 & 0,565 & 0,762 & \\
\hline 7 Müşteri Sadakati & 0,611 & 0,734 & 0,707 & 0,630 & 0,541 & 0,699 \\
\hline
\end{tabular}

\subsection{Bulgular}

Araştırma modelinin test edilmesi için gerçekleştirilecek yol analizi öncesinde, analizde yer alan değişkenler arasında çoklu bağlantı sorununun olmaması ve modeldeki örtük değișkenlerin çoklu bağlantı problemi yaratmaması amacıyla, bu değișkenlerin VIF (multi-collinearity) değerlerine bakılmaktadır. Değișkenler arasındaki ideal VIF değeri 3 ve daha altındaki değerlerdir (Hair vd., 2019). Elde edilen sonuçlar neticesinde VIF değerlerinin 3'ten küçük olduğu, göstergelerin beklenen VIF değerlerine sahip olduğu ve çoklu bağlantı problemi taşımadığı tespit edilmiştir. VIF değerleri, Tablo 5'de verilmektedir.

Tablo 5: Yapısal Modeldeki Örtük Değişkenlere İlişkin VIF Değerleri

\begin{tabular}{|l|l|l|}
\hline Bağımsız Değişkenler & Müşteri Tatmini & Müşteri Sadakati \\
\hline Duyusal Deneyim & 1.676 & 1.731 \\
\hline Duygusal Deneyim & 1.936 & 2.084 \\
\hline Düşünsel Deneyim & 2.268 & 2.416 \\
\hline Davranışsal Deneyim & 2.268 & 2.416 \\
\hline İlişkisel Deneyim & 1.785 & 2.080 \\
\hline Müșteri Tatmini & & 2.559 \\
\hline
\end{tabular}

Araştırma modelinin test edilmesi için yol analizi yapılmıștır. Araştırmanın amacı doğrultusunda oluşturulan hipotezlere ilişkin sonuçlar Tablo 6'da detaylı olarak gösterilmektedir. 
Sinan Çavuşoğlu, Bülent Demirağ, "Müșteri Deneyimi, Müşteri Tatmini ve Müşteri Sadakati Arasındaki İlişkinin İncelenmesi: Hazır Giyim Sektöründe Bir Araştırma”, İstanbul Gelişim Üniversitesi Sosyal Bilimler Dergisi, 8 (2), Ekim 2021, ss. 316-336.

Tablo 6: Yol Analizi Sonuçları

\begin{tabular}{|c|c|c|c|c|c|c|c|c|}
\hline Değișkenler & & Beta (ß) & Std. Hata & $t$ & $p$ & $R^{2}$ & $Q^{2}$ & Sonuç \\
\hline $\mathrm{H}_{1}$ Müşteri Deneyimi & $\begin{array}{l}\mathrm{M} . \\
\text { Tatmini }\end{array}$ &, 759 & 024 & 32,060 & $0,00^{* * *}$ & \multirow{6}{*}{0,569} & \multirow{6}{*}{0,346} & $\begin{array}{l}\text { Kabul } \\
\text { Edildi }\end{array}$ \\
\hline $\mathrm{H}_{1 \mathrm{a}}$ Duyusal & $\stackrel{\mathrm{M} .}{\mathrm{T}} \overrightarrow{\mathrm{atmini}}$ & , 147 & ,058 & 2,518 & $0,014^{*}$ & & & $\begin{array}{l}\text { Kabul } \\
\text { Edildi }\end{array}$ \\
\hline $\mathrm{H}_{1 \mathrm{~b}}$ Duygusal & $\begin{array}{l}\mathrm{M} . \\
\mathrm{T}\end{array}$ &, 241 & 057 & 4,271 & $0,00^{* * *}$ & & & $\begin{array}{l}\text { Kabul } \\
\text { Edildi }\end{array}$ \\
\hline $\mathrm{H}_{1 \mathrm{c}}$ Düşünsel & T. & , 240 & 059 & 4,060 & $0,00^{* * *}$ & & & $\begin{array}{l}\text { Kabul } \\
\text { Edildi }\end{array}$ \\
\hline $\mathrm{H}_{1 \mathrm{~d}}$ Davranışsal & $\begin{array}{l}\text { M. } \\
\text { Tatmini }\end{array}$ &,- 019 &, 050 & 0,381 & 0,701 & & & $\begin{array}{l}\text { Kabul } \\
\text { edilmedi }\end{array}$ \\
\hline $\mathrm{H}_{1 \mathrm{e}}$ İliş̧kisel & $\begin{array}{l}\text { M. } \\
\text { Tatmini }\end{array}$ & 340 & 051 & 6,711 & $0,000^{* * *}$ & & & $\begin{array}{l}\text { Kabul } \\
\text { Edildi }\end{array}$ \\
\hline $\mathrm{H}_{2}$ Müşteri Deneyimi & $\begin{array}{l}\text { M. } \\
\text { Sadakatł }\end{array}$ & 154 & 070 & 2,377 & $0,018^{*}$ & \multirow{6}{*}{0,532} & \multirow{6}{*}{0,405} & $\begin{array}{l}\text { Kabul } \\
\text { Edildi }\end{array}$ \\
\hline $\mathrm{H}_{2 \mathrm{a}}$ Duyusal & $\begin{array}{l}\text { M. } \\
\text { Sadakatł }\end{array}$ & , 141 & 053 & 2,670 & $0,006^{* *}$ & & & $\begin{array}{l}\text { Kabul } \\
\text { Edildi }\end{array}$ \\
\hline $\mathrm{H}_{2 \mathrm{~b}}$ Duygusal & $\begin{array}{l}\text { M. } \\
\text { Sadakat }\end{array}$ & 307 & ,063 & 4,907 & $0,00^{* * *}$ & & & $\begin{array}{l}\text { Kabul } \\
\text { Edildi }\end{array}$ \\
\hline $\mathrm{H}_{2 \mathrm{c}}$ Düşünsel & $\begin{array}{l}\text { M. } \\
\text { Sadakat' }\end{array}$ & , 136 & 061 & 2,222 & $0,021^{*}$ & & & $\begin{array}{l}\text { Kabul } \\
\text { Edildi }\end{array}$ \\
\hline $\mathrm{H}_{2 \mathrm{~d}}$ Davranışsal & $\begin{array}{l}\text { M. } \\
\text { Sadakat? }\end{array}$ & ,228 &, 050 & 4,596 & $0,00^{* * *}$ & & & $\begin{array}{l}\text { Kabul } \\
\text { Edildi }\end{array}$ \\
\hline $\mathrm{H}_{2 \mathrm{e}}$ İliş̧kisel & $\begin{array}{l}\text { M. } \\
\text { Sadakat? }\end{array}$ &,- 079 & 053 & 1,487 & 0,149 & & & $\begin{array}{l}\text { Kabul } \\
\text { edilmedi }\end{array}$ \\
\hline $\mathrm{H}_{3}$ M. Tatmini & $\begin{array}{l}\text { M. } \\
\text { Sadakat? }\end{array}$ & , 189 & 065 & 2,923 & $0,004^{* *}$ & & & $\begin{array}{l}\text { Kabul } \\
\text { Edildi }\end{array}$ \\
\hline
\end{tabular}

$p=<0,001^{* * *}, p=<0,01^{* *}, p=<0,05^{*}$

Yapılan analizler sonucunda elde edilen $\mathrm{R}^{2}$ sonucuna göre müşteri deneyim boyutları müșteri tatmininin yaklaşık \%57'sini açılarken, müșteri sadakatinin ise \%53'ünü açıklamaktadır. Ayrıca bağımsız değişkenler ile bağımlı değişkenler arasındaki ilgi düzeylerini $\left(Q^{2}\right)$ belirlemek amacıyla SmartPLS 3.0 programında "blindfolding" yöntemi kullanılmıştır. Hair vd. (2019)'ne göre bağımlı değişkenlerin $Q^{2}$ değerleri 0'dan büyük olması durumunda, modelin bağımlı değişkenlere yönelik tahmin doğruluğundan söz edilebilmektedir. Gerçekleştirilen analiz neticesinde iki bağımlı değişkenin $Q^{2}$ değerleri sıfırdan büyük çıkmıștır (Bknz. Tablo 6). Bu doğrultuda yapısal modelin bağımlı değişkenlere yönelik tahmin doğruluğundan söz edilebilir.

Yol analizi sonuçları incelendiğinde genel olarak müşteri deneyiminin $(\beta=, 759$, $\mathrm{p}<0,001)$ alt boyut olarak duyusal deneyimin $(\beta=147, \mathrm{p}<0,05)$, duygusal deneyimin $(ß=, 241, p<0,001)$, düşünsel deneyimin $(ß=, 240, p<0,001)$ ve ilişkisel deneyimin $(\beta=, 340$, $\mathrm{p}<0,001)$ müşteri tatmini ile istatistiksel olarak anlamlı bir ilişkiye sahip olduğu belirlenmiștir. $\mathrm{Bu}$ doğrultuda $\mathrm{H}_{1}, \mathrm{H}_{1 a}, \mathrm{H}_{1 b}, \mathrm{H}_{1 c}$ ve $\mathrm{H}_{1 e}$ hipotezleri kabul edilmiştir. Ancak davranışsal deneyimin $(ß=-, 019, p<0,001)$ müşteri tatmini üzerinde herhangi bir etkisinin olmadığı tespit edilmiştir. $\mathrm{Bu}$ doğrultuda $\mathrm{H}_{1 \mathrm{~d}}$ hipotezi kabul edilmemiştir. Müşteri deneyim ve boyutlarının müşteri sadakati üzerine etkisi incelendiğinde; müșteri deneyiminin $(\beta=, 154, p<0,01)$, duyusal deneyimin $(\beta=, 141, p<0,01)$, duygusal deneyimin $(\beta=, 307, p<0,001)$, düşünsel deneyimin $(\beta=, 136, p<0,05)$ ve davranıșsal deneyimin $(ß=, 228, p<0,001)$ müșteri sadakati ile istatistiksel olarak anlamlı bir ilișkiye sahip olduğu 
Sinan Çavuşoğlu, Bülent Demirağ, "Müșteri Deneyimi, Müşteri Tatmini ve Müşteri Sadakati Arasındaki İlişkinin İncelenmesi: Hazır Giyim Sektöründe Bir Araştırma”, İstanbul Gelişim Üniversitesi Sosyal Bilimler Dergisi, 8 (2), Ekim 2021, ss. 316-336.

belirlenmiştir. Bu doğrultuda $\mathrm{H}_{2}, \mathrm{H}_{2 \mathrm{a}}, \mathrm{H}_{2 \mathrm{~b}}, \mathrm{H}_{2 \mathrm{c}}$ ve $\mathrm{H}_{2 \mathrm{~d}}$ hipotezleri kabul edilmiştir. Ancak ilişkisel deneyimin $(ß=-, 079, p<0,001)$ müşteri sadakati üzerinde herhangi bir etkisinin olmadığı belirlenmiştir. $\mathrm{Bu}$ doğrultuda $\mathrm{H}_{2 \mathrm{e}}$ hipotezi kabul edilmemiştir.

Son hipotezde müşteri tatmininin müşteri sadakati üzerine olan etkisi belirlenmeye çalışılmıştır. Yol analizi sonucunda müşteri tatmininin $(\beta=, 189, p<0,01)$ müşteri sadakati ile istatistiksel olarak anlamlı bir ilişkiye sahip olduğu sonucuna ulașılmıştır. Dolayısıyla $\mathrm{H}_{3}$ hipotezi kabul edilmiștir.

\section{SONUÇ ve TARTIŞMA}

Tüketiciler, alternatiflerin sayısına bağlı olarak yararlandıkları bir üründen çok daha fazlasını elde etmek istemektedirler. Tüketiciler modern dünyada artık sadece ürünleri değil aynı zamanda ürünlerin anlamlarını da tüketmektedir. Bu nedenle işletmelerin, küresel rekabet ortamında farkındalık yaratarak her anlamda rakiplerinin önünde yer almak adına somut ürün özelliklerinin yanı sıra tüketicilerin ürünle yaşadıkları ilişkilerin sonucunda oluşan müşteri deneyimlerine de odaklanmaları gerekmektedir. Ürüne/markaya yönelik müşteri deneyimlerinin düzenli olarak takip edilmesi, olumsuz müşteri deneyimi oluşturan unsurların tespit edilmesine ve düzeltici önlemler alınmasına olanak sağlayacaktır. İşletmeye yönelik tatmin ve sadakat gibi davranışsal niyetlerin müşteri deneyimi ile olan ilişkisine yönelik literatürde çalışmalara rastlanılmaktadır (Trini ve Salim, 2018; De Klerk ve Tselepis, 2007; Mbama ve Ezepue, 2018; Fernando vd., 2018; Shim vd., 2015). Gerçekleștirilen çalışmalar müșteri deneyiminin müşteri tatmini ve sadakati ile olan güçlü ilișkisini yansıtmaktadır.

Çalışmada, müşteri deneyiminin müşteri tatmini ve müşteri sadakati üzerindeki etkisinin incelenmesine odaklanılmıştır. Yabancı literatürde konuya ilişkin önemli çalışmalar olmasına karşın yerli literatürde böylesine kapsamlı bir çalışmaya rastlanılmamıştır. Ancak konunun farklı kültürlerde incelenmesinde yarar görülmektedir. $\mathrm{Bu}$ nedenle çalışmada müșteri deneyiminin beş boyutlu (duyusal, duygusal, düşünsel, davranışsal ve ilişkisel) yapısının müşteri tatmini ve sadakati üzerindeki etkisinin incelenmesi gerçekleștirilmiştir.

Çalışmada ulaşılan ilk sonuç; müşteri deneyimi ve duyusal, duygusal, düșünsel, ilişkisel boyutlarının müşteri tatmini ile anlamlı bir ilişkiye sahip olduğunun tespit edilmesidir. Çalışmada ulaşılan bu sonuç genel olarak literatürdeki çalışmalarla tutarlılık göstermektedir (Trini ve Salim, 2018; De Klerk ve Tselepis, 2007; Yu vd., 2017; Borishade vd., 2018). Müşteri deneyim ve boyutlarının müşteri tatmini ile anlamlı ilişkisine yönelik bulunan sonuç, tüketicilerin alışveriş yaptıkları mağazaların atmosferine, görsel ve duyusal öğelere, yeni ürüne yönelik beklentilerinin karşılanmasına bağlı olarak tatmin seviyelerinin etkilendiğini göstermektedir. Bu nedenle işletmelere olumlu deneyim yaratan mağaza atmosferi, iç ve dış dekorasyonlar gibi fiziksel öğelerin yanı sıra müşteri beklentilerini duygusal olarak karşılayan öğelere odaklanılması ve ayrıca tüketicilerin sosyal ilişkilerine önem vermeleri tavsiye edilmektedir.

Elde edilen sonuçların aksine müşteri deneyim boyutlarından davranışsal boyutun müşteri tatminini etkilemediği sonucuna ulaşılmıştır. Benzer bir başka sonuç Yuan ve Wu (2008) tarafından elde edilmiştir. Yuan ve Wu, kahve işletmelerini ziyaret eden müșterilerin davranışsal deneyimlerinin müșteri tatminini etkilemediğini belirlemişlerdir. Davranıșsal deneyim, insanların yaşam tarzlarını ve alternatif yașam biçimlerini etkilemektedir. $\mathrm{Bu}$ boyutun oluşmasında reklamların, tanıtımların ve kampanyaların önemli bir etkisi bulunmaktadır. Davranışsal boyut, işletmeler tarafından sunulan mal ve hizmetlerle bir his, etki ve ilişki duygusu geliştirir. Bu bakımdan giyim mağazalarını ziyaret eden tüketiciler hizmet mükemmelliğine ve eğlenceye daha fazla önem vermiş olabilir. 
Sinan Çavuşoğlu, Bülent Demirağ, "Müșteri Deneyimi, Müşteri Tatmini ve Müşteri Sadakati Arasındaki İlişkinin İncelenmesi: Hazır Giyim Sektöründe Bir Araştırma”, İstanbul Gelişim Üniversitesi Sosyal Bilimler Dergisi, 8 (2), Ekim 2021, ss. 316-336.

Çalıșmadaki bir diğer sonuç, müşteri deneyimi ve duyusal, duygusal, düşünsel, davranışsal boyutlarının müşteri sadakati ile istatistiksel olarak anlamlı bir ilişkiye sahip olduğuna yöneliktir. Çalışmada elde edilen bu sonuç genel olarak literatürde yer alan çalışmalarla tutarlılık göstermektedir (Fernando vd., 2018; Huong vd., 2016; Shim vd., 2015; Imbug vd., 2018 vd.). Fernando vd. (2018), Sri Lanka'da hazır giyimde moda ürünleri tercih eden tüketiciler üzerinden gerçekleștirdikleri çalışmada müșteri deneyiminin duyusal, duygusal, düşünsel ve davranışsal boyutlarının marka sadakati üzerinde pozitif etkisi olduğu sonucuna ulaşmışlardır. Huong vd. (2016),Vietnam DaNang üniversitesinde uluslararası iki giyim markasını kullanan 18-35 yaşları arasındaki 285 katılımcı ile gerçekleștirdikleri çalışmalarında, müșteri deneyiminin tüm boyutlarının marka sadakati ile pozitif bir ilişkiye sahip olduğu tespit edilmiştir. Elde edilen sonuca bağlı kalarak işletmelerin müşteri sadakati yaratmak adına görsel olarak çekicilik yaratan fiziksel öğelere, mağaza atmosferine, rahatlatıcı ve samimi mağaza ortamına, müşteri ilişkilerini geliştirmek adına basılı ve görsel iletişim kanallarına odaklanmaları tavsiye edilmektedir.

Elde edilen sonuçların aksine ilişkisel boyutun müşteri sadakatini etkilemediği sonucuna ulaşılmıștır. Venkat (2007) önde gelen bir üreticinin 140 müșterisi üzerine yapmış olduğu çalışmasında müşteri deneyiminin müşteri sadakatini etkilemediği sonucuna ulaşmıștır. Bu sonuç genel olarak elde edilen analiz sonuçlarını desteklemese de ilişkisel deneyim anlamında elde edilen sonucu desteklemektedir. Müşteriler ilişkisel deneyimlerle ürün veya işletmelerle bağlantı kurmaktadır. $\mathrm{Bu}$ bakımdan ürün veya ișletmelerin hizmet yönünden kaliteli olması, eğlenilebilirlik yönünden bireyleri sosyal topluluğa dâhil etmesi ve estetik yönünden ilgi çekmesi, giyim mağazalarını ziyaret eden tüketicilerin bu boyutlara daha çok yönelmelerini sağlamış olabilir. Potansiyel olarak verimlilik ve ekonomik değerler ilişkisel deneyimde geri planda kalan bir unsur olarak görülebilir.

Çalışmada ulaşılan son sonuç ise müşteri tatmininin müşteri sadakati ile anlamlı bir ilişkiye sahip olduğuna yöneliktir. Bu sonuç gerçekleştirilen çalışmalarla tutarlılık göstermektedir (Sheng ve Liu, 2010; Kandampully ve Suhartanto, 2000; Nobar ve Rostamzadeh, 2018; Arokiasamy, 2013). İșletmeler, müșteri sadakati yaratmak adına müșterinin tatminine odaklanmalıdırlar. Tatmin yaratmak adına müşteri beklentilerine odaklanılması, beklentilere yönelik politikalar geliştirilmesi ve uygulanması önemli gözükmektedir. Bu kapsamda müşteriye yönelik vaatlerin zamanında yerine getirilmesi, sonuca ulaşma ihtimali bulunmayan vaatlerin sunulmaması ve vaatlerin ihtiyaçlara cevap verecek şekilde gerçekleştirilmesi tavsiye edilmektedir.

Bütün çalışmalarda olduğu gibi bu çalışmanın da birtakım kısıtları bulunmaktadır. Çalışma, hazır giyim sektöründe gerçekleştirilmiştir. Sonraki çalışmalarda farklı sektörlerde konunun irdelenmesinin araștırmacılara geniş bir perspektif sunacağına inanılmaktadır. Ayrıca çalışma sınırlı bir örneklem üzerinden gerçekleştirilmiştir. Daha büyük bir çalışma kitlesinden veri toplanmasının konuya değişik bakış açıları kazandıracağına inanılmaktadır. Son olarak farklı değişkenlerin de araștırmaya dahil edilerek konunun genişletilmesinin literatüre ve uygulayıcılara farklı bakış açıları sunacağı belirtilebilir.

\section{KAYNAKÇA}

AJZEN, I. \& FISHBEIN, M. (1980). Understanding attitudes and predicting social behavior. Englewood Cliffs, NJ: Prentice-Hall.

ALI, F., RASOOLIMANESH, S. M., SARSTEDT, M., RINGLE, C. M. \& RYU, K. (2018). An assessment of the use of partial least squares structural equation modeling (PLS- 
Sinan Çavuşoğlu, Bülent Demirağ, "Müșteri Deneyimi, Müşteri Tatmini ve Müşteri Sadakati Arasındaki İlişkinin İncelenmesi: Hazır Giyim Sektöründe Bir Araştırma”, İstanbul Gelişim Üniversitesi Sosyal Bilimler Dergisi, 8 (2), Ekim 2021, ss. 316-336.

SEM) in hospitality research. International Journal of Contemporary Hospitality Management, 30(1), 514-538.

ALİ, F., HUSSAIN, K. \& RAGAVAN, N. A. (2014). Memorable customer experience: examining the effects of customers experience on memories and loyalty in Malaysian resort hotels. 5thAsia EuroConference 2014, Procedia - Social and Behavioral Sciences 144(2014), 273-279.

AL-MSALLAM, S. (2015). The relationship between customer satisfaction and customer loyalty in the banking sector in Syria. Journal of Marketing and Consumer Research, 7, 27-35.

ANDERSON, W. E., FORNELL, C. \& LEHMANN, D. R. (1994). Customer Satisfaction, market share and profitability: finding from Sweeden. Journal of Marketing, 58(3), 53-66.

AROKIASAMY, A. R. (2013). The Impact of Customer Satisfaction on Customer Loyalty and Intentions to Switch in the Banking Sector In Malaysia. The Journal of Commerce, 5(1). 14-21.

BACKMAN, S. J. \& CROMPTON, J. L. (1991). The usefulness of selected variables for predicting activity loyalty. Leisure Sciences, 13(3), 205-220.

BARARI, M., ROSS, M. \& SURACHARTKUMTONKUN, J. (2019). Negative and positive customer shopping experience in an online context. Journal of Retailing and Consumer Services, 53.

BORISHADE, T., KEHINDE, O., IYIOLA, O., OLOKUNDUN, M. IBIDUNNI, A., DIRISU, J. \& OMOTOYINBO, C. (2018). Dataset on customer experience and satisfaction in healthcare sector of Nigeria. Data in Brief, 20, 1850-1853. 53-55.

BROWN, G. H. (1952). Brand loyalty - fact or fiction?. Advertising Age, 23 (June 9),

BROWN, S. A. (1992). Total quality service: How organizations use it to create a competitive advantage. Prentice Hall Canada Inc. Scarborough, Ontario, Canada.

CHANG, R. C., KIVELA, J. \& MAK, A. H. (2011). Attributes that Influence the Evaluation of Travel Dining Experience: When East Meets West. Tourism Management, 32(2), 307-316.

CHEN, M. F. \& WANG, L. H. (2009). The moderating role of switching barriers on customer loyalty in the life insurance industry. The Service Industries Journal, 29, 11051123.

CUNNINGHAM, R. M. (1961). Customer loyalty to store and brand. Harvard Business Review, 39(6), 127-137.

ÇAVUŞOĞLU, S. \& DURMAZ, Y. (2020). Deneyimsel Pazarlama ve Yeşil Davranış. İstanbul: Hiper Yayın.

DAY, G. S. (1969). A two-dimensional concept of brand loyalty. Journal of Advertising Research, 9(3), 29-35.

DE KLERK, H. \& TSELEPIS, T. (2007). The early adolescent female clothing consumer: Expectations, evaluation and satisfaction with fit as part of the appreciation of clothing quality. Journal of Fashion Marketing and Management, 11(3), 413-428.

DEMİRAĞ, B. \& DURMAZ, Y. (2020). Marka Yönetimi. İstanbul: Hiper Yayın.

DICK, A. S. \& BASU, K. (1994). Customer loyalty: Toward an integrated conceptual framework. Journal of Academy of Marketing Science, 22(2), 99-113.

DOVALIENĖ, A., GADEIKJENE, A. \& PILIGRIMIENE, Z. (2007). Customer satisfaction and its importance for long-term relationships with service provider: the case of odontology services. Engineering Economics, 55(5), 59-67.

DRAKE, C., GWYNNE, A. \& WAITE, N. (1998). Barclays Life customer satisfaction and loyalty tracking survey: a demonstration of customer loyalty research in practice. International Journal of Bank Marketing, 16(7), 287-292. 
Sinan Çavuşoğlu, Bülent Demirağ, "Müșteri Deneyimi, Müşteri Tatmini ve Müşteri Sadakati Arasındaki İlişkinin İncelenmesi: Hazır Giyim Sektöründe Bir Araştırma", İstanbul Gelişim Üniversitesi Sosyal Bilimler Dergisi, 8 (2), Ekim 2021, ss. 316-336.

66.

EGAN, T. (1998). The Swoon of the Swoosh. The New York Times, 13 September,

EVANSCHITZKY, H. \& WUNDERLICH, M. (2006). An examination of moderator effects in the four-stage loyalty model. Journal of Service Research, 8(4), 330-345.

FERNANDO, H. S. M., KUMARA, H. H. S. N., MENDIS, H. I. A. \& WETTAWA, W. M. B. S. (2018). Effects of Brand Experience on Consumer Brand Loyalty in Fashion Retail Industry: Moderating the Role of Gender. Global Journal of Management and Business Research: E Marketing, 18(7), 47-56.

FORNELL, C. (1992). A national customer satisfaction barometer: The Swedish experience. Journal of Marketing, 55, 6-21.

FORNELL, C. \& LARCKER, D. F. (1981), Structural Equation Models With Unobservable Variables and Measurement Error: Algebra and Statistics, Journal of Marketing Research, May, 382-388.

FRAERING, M. \& S. MINOR, M. (2013). Beyond loyalty: customer satisfaction, loyalty, and fortitude. Journal of Services Marketing, 27(4), 334-344.

GENTILE, C., SPILLER N. \& NOCI G. (2007). How to sustain customer experience: An overview of experience components that co-create value with the customer. European Management Journal, 25(5), 395-410.

GILBERT, A., CHURCHILL J. R. \& SURPRENANT, C. (1982). An Investigation into the determinants of customer satisfaction. Journal of Marketing Research (JMR), 19, 491504.

GÜLTEKIN, B. \& KEMENT, Ü. (2018). Müşteri İlişkileri Yönetimi Temel Kavramlar ve Uygulamalar. Ankara: Nobel Yayıncılık.

HAIR, J. F., RINGLE, C. M. \& SARSTEDT, M. (2011). PLS-SEM: indeed a silver bullet. Journal of Marketing Theory and Practice, 19(2), 139-152.

HAIR, J. F., RISHER, J. J., SARSTEDT, M. \& RINGLE, C. M. (2019). When to use and how to report the results of PLS-SEM. European Business Review, 31(1), 2-24.

HAIR, J. F., SARSTEDT, M., RINGLE, C. M. \& MENA, J. A. (2012). An Assessment of the Use of Partial Least Squares Structural Equation Modeling in Marketing Research. Journal of the Academy of Marketing Science, 40(3), 414-433.

HAIR, J., F., BLACK, W., BABIN, B. \& ANDERSON, R. E. (2010). Multivariate Data Analysis (7th ed.). Upper Saddle River, NJ, USA: Prentice-Hall.

HAN, X., KWORTNIK, R. J. \& WANG, C. (2008). Service loyalty: An integrative model and examination across service contexts. Journal of Service Research, 11, 22-42.

HARARY, F. \& LIPSTEIN, B. (1962). The dynamics of brand loyalty: a Markovian approach. Operations Research, 10(1), 19-40.

HENSELER, J., RINGLE, C. M. \& SINKOVICS, R. R. (2009). The use of partial least squares path modeling in international marketing. In New challenges to international marketing. Emerald Group Publishing Limited.

HOWARD, J. A. \& SHETH, J. N. (1969). The theory of buyer behavior. In Journal of the American Statistical Association, 467-487.

HU, L. T. \& BENTLER, P. M. (1999). Cutoff criteria for fit indexes in covariance structure analysis: Conventional criteria versus new alternatives. Structural equation modeling: A multidisciplinary journal, 6(1), 1-55.

HUH, J. (2002). Tourist satisfaction with cultural/heritage sites: the virginia historic triangle. (Master Thesis). Faculty of Virginia Polytechnic. Institute and State University. US.

HUONG, P. T. L., HONG, N. T. \& KHAI, T. T. (2016). Effects of Brand Experience on Brand Loyalty in Fashion Retail Business. Journal of Economic Development, 23(3), 7388. 
Sinan Çavuşoğlu, Bülent Demiră̆, "Müşteri Deneyimi, Müşteri Tatmini ve Müşteri Sadakati Arasındaki İlişkinin İncelenmesi: Hazır Giyim Sektöründe Bir Araştırma”, İstanbul Gelişim Üniversitesi Sosyal Bilimler Dergisi, 8 (2), Ekim 2021, ss. 316-336.

IHALAINEN, M. (2011). Competitive advantage through customer satisfaction. Markus Ihalainen Degree Programme in Business Management Bachelor's Thesis. Laurea University of Applied Sciences.

ILIESKA, K. (2013). Customer satisfaction index-as a base for strategic marketing management. TEM Journal, 2(4), 327-331.

IMBUG, N., AMBAD, S. N. A. \& BUJANG, I. (2018). The Influence of Customer Experience on Customer Loyalty in Telecommunication Industry. International Journal of Academic Research in Business and Social Sciences, 8(3), 103-116.

JACOBY, J \& KYNER, D. B. (1973). Brand loyalty versus repeat purchasing behaviour. Journal of Marketing Research, 10, 1-9.

JOHNSTON, R. \& KONG, X. (2011). The customer experience: a road-map for improvement. Managing Service Quality, 21(1), 1-24.

KAISER, H. F. (1974). An index of factorial simplicity. Psychometrika, 39(1), 3136.

KANDAMPULLY, J. \& SUHARTANTO, D. (2000). Customer loyalty in the hotel industry: the role of customer satisfaction and image. International Journal of Contemporary Hospitality Management, 12(6), 346-351

KEMENT, Ü. \& ÇAVUŞOĞLU, S. (2017). Hafızaya Yönelik Müşteri Deneyimlerinin Müşteri Sadakatine Etkisi: Yeșil Oteller Örneği. Uluslararası Sosyal ve Eğitim Bilimleri Dergisi, 4(8), 172-194.

LEE, M., LEE, S. \& KOH, Y. (2019). Multisensory experience for enhancing hotel guest experience: Empirical evidence from big data analytics. International Journal of Contemporary Hospitality Management, 31(11), 4313-4337.

LEE, S. H., CHANG, S. C., HOU, J. S. \& LIN, C. H. (2008). Night Market Experience and Image f Temporary Residents and Foreign Visitors. International Journal of Culture, Tourism and Hospitality Research, 2(3), 217-233.

LEMON, K. N. \& VERHOEF, P. C. (2016). Understanding Customer Experience Throughout the Customer Journey. Journal of Marketing, 80(6), 69-96.

LENINKUMAR, V. (2017). The Relationship between Customer Satisfaction and Customer Trust on Customer Loyalty. International Journal of Academic Research in Business and Social Sciences, 7(4), 450-465.

MARTÍN-CONSUEGRA, D., MOLINA, A. \& ESTEBAN, A. (2007). An integrated model of price, satisfaction and loyalty: an empirical analysis in the service sector. Journal of Product \& Brand Management, 16(7), 459-468.

MATTILA, A. S. (2001). Emotional Bonding and Restaurant Loyalty. Cornell Hotel and Restaurant Administration Quarterly, 42(6), 73-79.

MBAMA, C. \& EZEPUE, P. (2018). Digital banking, customer experience and bank financial performance: UK customers' perceptions. International Journal of Bank Marketing, 36(2), 230-255.

NADIRI, H. \& GUNAY, G. N. (2013). An empirical study to diagnose the outcomes of customers' experiences in trendy coffee shops. Journal of Business Economics and Management, 14(1), 22-53.

NAGASAWA, S. (2008). Customer Experience Management Influencing on Human Kansei to Management of Technology. The TQM Journal, 20(4), 312-323.

NEWMAN, J. W. \& WERBEL, R. A. (1973). Multivariate analysis of brand loyalty for major household appliances. Journal of Marketing Research, 10, 404-409.

NGUYEN, H. T., NGUYEN, H., NGUYEN, N. D. \& PHAN, A. C. (2018). Determinants of Customer Satisfaction and Loyalty in Vietnamese Life-Insurance Setting. Sustainability, 10, 1151.

NOBAR, H. B. K. \& ROSTAMZADEH, R. (2018). The Impact of Customer Satısfactıon, Customer Experience And Customer Loyalty on Brand Power: Empirical 
Sinan Çavuşoğlu, Bülent Demirağ, "Müşteri Deneyimi, Müşteri Tatmini ve Müşteri Sadakati Arasındaki İlişkinin İncelenmesi: Hazır Giyim Sektöründe Bir Araştırma”, İstanbul Gelişim Üniversitesi Sosyal Bilimler Dergisi, 8 (2), Ekim 2021, ss. 316-336.

Evidence from Hotel Industry. Journal of Business Economics and Management, 19(2), 417-430.

OLIVER, R. L. (1999). Whence consumer loyalty?. Journal of Marketing, Fundamental Issues and Directions for Marketing, 63(4), 33-44.

OLIVER, R. L. (1997). Loyalty and profit: long-term effects of satisfaction.

Satisfaction: A behavioural perspective on the consumer, McGraw-Hill Companies, Inc., New York, NY.

PINE, B. J. \& GILMORE, J. H. (1999). The Experience Economy: Work is Theatre and Every Business a Stage. Harvard Business School Press Boston, Massachusetts.

RADDER, L. \& HAN, X. (2013). Perceived quality, visitor satisfaction and conative loyalty in south african heritage museums. International Business \& Economics Research Journal, 12(10), 1261-1271.

SCHMITT, B. (1999). Experiential Marketing. Journal of Marketing Management, 15(1-3), 53-67.

SHAW, C. \& IVENS, J. (2005). Building great customer experiences. New York: Palgrave Macmillan.

SHENG, T. \& LIU, C. (2010). An empirical study on the effect of e-service quality on online customer satisfaction and loyalty. Nankai Business Review International, 1(3), 273-283.

SHIM, I. S., FORSYTHE, S. \& KWON, W-S. (2015). Impact Of Online Flow On Brand Experience And Loyalty. Journal of Electronic Commerce Research, 16(1), 56-71.

TRINI, D. \& SALIM, M. N. (2018). Customer Experience Marketing (CEM), Customer Satisfaction and Customer Trust Affects Customer Loyalty: A Study on Star Hotels in Jakarta Province. Business Management and Strategy, 9(2), 100-116.

TUCKER, W. T. (1964). The development of brand loyalty. Journal of Marketing Research, 1 (August), 32-35.

VENKAT, R. (2007). Impact of Customer Experience on Satisfaction, Brand Image and Loyalty: A Study in a Business-to-Business Context. Journal of Marketing, 3.

VERHOEF, P. C., LEMON, K.N., PARASURAMAN, A., ROGGEVEEN, A., TSIROS, M. \& SCHLESINGER, L. A. (2009). Customer Experience Creation: Determinants, Dynamics and Management Strategies. Journal of Retailing 85 (1), 31-41.

VOORHEES, C. M., BRADY, M. K., CALANTONE, R. \& RAMIREZ, E. (2016).

Discriminant validity testing in marketing: An analysis, causes for concern, and proposed remedies. Journal of the Academy of Marketing Science, 44(1), 119-134.

WANG, Y., LO, H. P., CHI, R. \& YANG, Y. (2004). An integrated framework for customer value and customer-relationship-management performance: A customerbased perspective from China. Managing Service Quality,14(2/3), 169-182.

WESTBROOK, R. \& REILLY, M. D. (1983). Value-percept disparity: an alternative to the disconfirmation of expectations theory of consumer satisfaction, in Bagozzi, R.P, Tybout, A.M (Eds), Advances in Consumer Research, Association for Consumer Research, Ann Arbor, MI, 256-261.

WIJAITHAMMARIT, S. \& TAECHAMANEESTIT, T. (2012). Customer Experience Management Influences Customer Loyalty: Case Study of Supercenters in Thailand. International Proceedings of Economics Development \& Research, 50(11), 47 - 52.

YANG, Z. Y. \& HE, L. Y. (2011). Goal, Customer Experience and Purchase Intention in a Retail Context in China: An Empirical Study. African Journal of Business Management, 5(16), 6738-6746.

YAŞLIOĞLU, M. M. (2017). Sosyal bilimlerde faktör analizi ve geçerlilik: Keşfedici ve doğrulayıcı faktör analizlerinin kullanılması. İstanbul Üniversitesi İşletme Fakültesi Dergisi, 46, 74-85. 
Sinan Çavuşoğlu, Bülent Demirağ, "Müșteri Deneyimi, Müşteri Tatmini ve Müşteri Sadakati Arasındaki İlişkinin İncelenmesi: Hazır Giyim Sektöründe Bir Araştırma”, İstanbul Gelişim Üniversitesi Sosyal Bilimler Dergisi, 8 (2), Ekim 2021, ss. 316-336.

YAZICI, T. (2013). Proposing a Model to Examine the Effect of Experiential Marketing and Perceived Values on Satisfaction and Behavioral Intentions of Turkish Dragon Fest Participants. Unpublished doctoral dissertation, Middle East Technical University.

YU, Y., LI, X. \& JAI, T. (2017). The impact of green experience on customer satisfaction: evidence from TripAdvisor. International Journal of Contemporary Hospitality Management, 29(5), 1340-1361.

YUAN, Y-H. \& WU, C. (2008). Relationship among Experiential Marketing, Experiential Value, and Customer Satisfaction. Journal of Hospitality and Tourism Research, 32(3), 387-410.

\section{Summary}

In recent years, businesses have become more and more concerned with customer experience to raise awareness of their competitors. The modern marketing concept forces businesses to understand and manage the experiences of the products they produce in their customers after sales. The concept of customer experience was dealt with in the 1990s and 1999s book, "Economics of Experience", and classical economists stated that the economy of experience was the result of researches containing comprehensive evaluations on consumer experiences. It contains judgmental statements regarding customer experience, consumer expectations and service evaluations. Businesses are likely to become more advantageous than their competitors if they can reduce the factors of negative customer experience and strengthen customer satisfaction and loyalty in order to achieve their goals.

Establishing customer satisfaction and loyalty by businesses, maintaining strong relationship with loyal customers, is important for gaining competitive advantage. Customers who have a loyalty to a brand or organization become insensitive to competitors' marketing efforts and even become a brand advocate because they have a strong intention to maintain their relationship with the business.

In this study, customer experience dimensions were examined as five dimensions (sensory experience, emotional experience, intellectual experience, behavioral experience and relational experience) as used in Schmitt study. The relationship between each customer experience dimension, customer satisfaction and customer loyalty has been analyzed in the garment industry based on customer perceptions and evaluations. According to the results of the analysis, sensory, emotional, intellectual and relational dimensions of customer experience have statistically significant relationship with customer satisfaction. In addition, it was determined that the sensory, emotional, intellectual and behavioral dimensions of the customer experience had statistically significant relationship with customer loyalty. As a result of the analysis, behavioral dimension did not affect customer satisfaction and relational dimension did not affect customer loyalty. 